\title{
AKIBAT HUKUM PERKAWINAN TIDAK DICATAT TERHADAP ISTRI DAN ANAK ATAS HAK KEBENDAAN MENURUT HUKUM ISLAM DI INDONESIA
}

\author{
Siah Khosyi'ah \\ Fakultas Syari'ah dan Hukum UIN Sunan Gunung Djati Bandung \\ Email: skhosyiah@gmail.com
}

\begin{abstract}
This paper describes the legal consequences of marriage were not recorded on the wives and children of the right material according to Islamic law in Indonesia, so this article is focused on the history of marriage in Indonesia, marriage is not recorded, and the legal consequences of marriage were not recorded for the right material. Legal remedies that can be done to make the recognition of the state for the marriage were not recorded, namely through the filing legalitation of marriage (isbat nikah) to the Islamic Courts. In Islamic Law Compilation explained that: who has the right to apply for legalitation of marriage (isbat nikah) is a husband or wife, their children, the guardian of marriage, and interested parties.
\end{abstract}

\begin{abstract}
Abstrak
Tulisan ini menjelaskan akibat hukum perkawinan tidak dicatat terhadap istri dan anak atas hak kebendaan menurut hukum Islam di Indonesia, dengan demikian tulisan ini lebih difokuskan terhadap sejarah perkawinan di Indonesia, perkawinan tidak dicatat, dan akibat hukum perkawinan tidak dicatat terhadap hak kebendaan. Sedangkan upaya hukum yang dapat dilakukan untuk dapat pengakuan negara bagi perkawinan yang tidak dicatat, yaitu melalui pengajuan isbat nikah ke Pengadilan Agama. Dalam Kompilasi Hukum Islam dijelaskan bahwa: yang berhak mengajukan permohonan isbat nikah ialah suami atau istri, anak-anak mereka, wali nikah, dan pihak yang berkepentingan.
\end{abstract}

Kata Kunci:

Perkawinan Tidak Dicatat, Istri dan Anak, Hak Kebendaan

\section{A. Pendahuluan}

Secara operasional perkawinan merupakan sarana untuk membangun keluarga dalam suatu struktur yang bersifat khusus, satu sama lain dalam keluarga itu mempunyai ikatan apakah lewat hubungan darah atau lewat perkawinan. Ikatan tersebut membawa pengaruh pada saling berharap (mutual expectation) yang sesuai dengan ajaran agama, dikukuhkan dengan kekuatan hukum dan secara individual mempunyai ikatan batin sehingga memunculkan hak dan kewajiban dalam sebuah keluarga yang dibentuk dalam suatu perkawinan.

Dasar sebuah keluarga dalam Islam adalah perkawinan dan adanya ikatan darah, Islam mengakui nilai-nilai sebuah hubungan antara pria dan wanita sehingga menganjur- kan pernikahan, itulah sebabnya Islam tidak menyenangi selibat (tidak mau menikah). Anjuran pernikahan dalam Islam memiliki tujuan yang jelas dan menghargai sebuah lembaga perkawinan agar setiap orang memperoleh kepuasan parasaan, sebagai bentuk mekanisme untuk mengurangi ketegangan, membiakkan keturunan dan kedudukan sosial seseorang secara absah, serta memperkuat pendekatan dalam keluarga dan solidaritas kelompok.

Hak dan kewajiban keluarga tidaklah sekedar ditentukan oleh ikatan darah maupun hubungan perkawinan saja akan tetapi keduanya saling mempengaruhi, bahkan hak dan kewajiban dalam suatu keluarga tidak sekedar merupakan hak privat dari keluarga itu sendiri tapi bersandar pada masyarakat 
sekitarnya, itulah sebabnya rasa saling harap dalam suatu keluarga tidak saja dikukuhkan institusinya oleh hubungan kekeluargaan saja, tetapi berkaitan dengan keanggotaan masyarakat besar dalam sebuat sistem sosial yang besar pula.

Pada awal Islam pembentukan sebuah keabsahan keluarga diwujudkan dengan pernikahan dan kepemilikan hamba sahaya sebagai polarisasi kemanusiaan yang sebelumnya menjadi kebiasaan masyarakat, walaupun akhirnya kepemilikan hamba sahaya dinilai sebagai pergudikan yang diharamkan dalam al-Quran. Hadirnya Islam membawa perubahan pandangan tentang pernikahan karena pernikahan dalam Islam merupakan akad yang menghalalkan kedua belah pihak antara antara laki-laki dan perempuan untuk hidup bersama mencapai tujuan perkawinan yaitu sakinah, mawaddah dan warahmah. Sehingga bisa dipahami pernikahan sebagai akad untuk beribadah kepada Allah, akad untuk menegakkan syariat Allah, akad untuk membangun, meniti hari-hari dalam kebersamaan rumah tangga dengan tujuan tersebut. Pernikahan berarti akad untuk saling melindungi dan akad untuk tidak melakukan pelanggaran dan saling menyakiti hati dan perasaan. Konsep ini sejalan dengan surat al-Nisâ ayat 20-21:

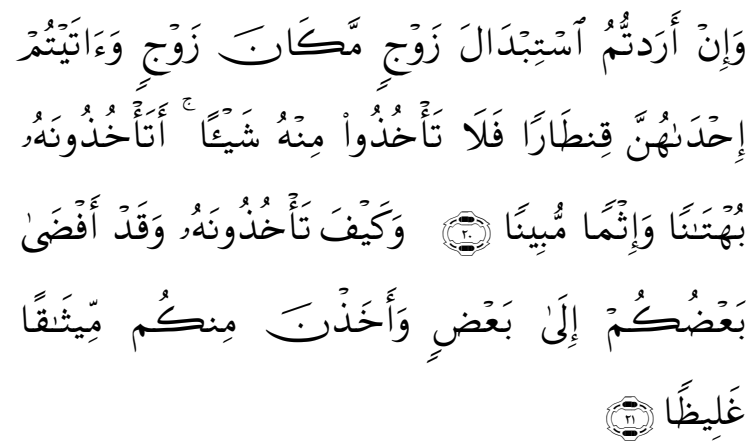

Dan jika kamu ingin mengganti istrimu dengan istri yang lain, sedang kamu telah memberikan kepada seseorang di antara mereka harta yang banyak, maka janganlah kamu mengambil kembali dari padanya barang sedikitpun. Apakah kamu akan mengambilnya kembali dengan jalan tuduhan yang Dusta dan dengan (menanggung) dosa yang nyata. Bagaimana kamu akan mengambilnya kembali, Padahal sebagian kamu telah bergaul (bercampur) dengan yang lain sebagai suami-istri. dan mereka (istri- istrimu) telah mengambil dari kamu perjanjian yang kuat.

Mujâhid dan 'Ikrimah memahami kalimat mîtsâqan galîzhâ adalah 'aqdun al-Nikâh,' penafsiran tersebut didukung dengan adanya hadits yang berbunyi:

$$
\text { فأخذ تموهن بأمانات الله }
$$

Islam memandang pernikahan bukan sebagai sarana untuk mencapai kenikmatan lahiriah semata, tetapi bagian dari pemenuhan naluri yang didasarkan pada aturan Allah (bernilai ibadah). Tujuannya sangat jelas, yaitu membentuk keluarga yang sakinah (tenang), mawaddah (penuh cinta), dan rahmah (kasih sayang) QS. al-Rûm ayat: 21

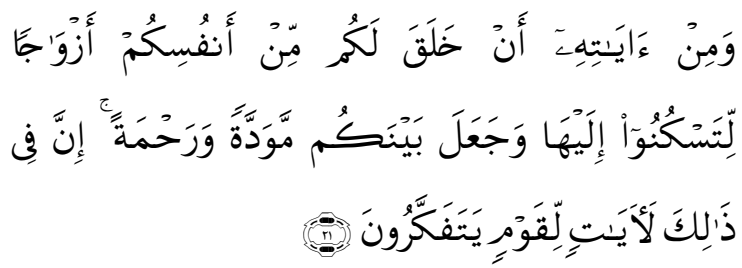

Dan di antara tanda-tanda kekuasaanNya ialah Dia menciptakan untukmu istri-istri dari jenismu sendiri, supaya kamu cenderung dan merasa tenteram kepadanya, dan dijadikan-Nya di antaramu rasa kasih dan sayang. Sesungguhnya pada yang demikian itu benar-benar terdapat tanda-tanda bagi kaum yang berpikir.

Dengan begitu, pernikahan akan mampu memberikan kontribusi bagi kesatabilan dan ketentraman masyarakat, karena kaum pria dan wanita dapat memenuhi naluri seksualnya secara benar dan sah. Lebih dari itu, pernikahan dalam Islam adalah bagian dari proses keberlangsungan generasi manusia secara universal, QS. al-Hujurât ayat: 13 .

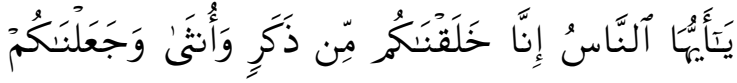

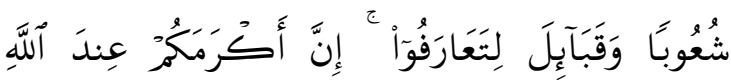

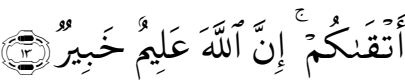

Hai manusia, Sesungguhnya Kami menciptakan kamu dari seorang laki-laki dan seorang perempuan dan menjadikan ka-

1 Muhammad 'Alî al-Shâbûnî, Tafsîr Âyât alAhkâm (Beirut: Dâr al-Kutûb al-'Alamiyyah. 1999), hlm. 332. 
mu berbangsa-bangsa dan bersuku-suku supaya kamu saling kenal-mengenal. Sesungguhnya orang yang paling mulia di antara kamu disisi Allah ialah orang yang paling taqwa diantara kamu. Sesungguhnya Allah Maha mengetahui lagi Maha Mengenal.

Pada masa ulama mazhab misalnya, pernikahan tersebut menjadi kajian yang menarik sehingga para ulama saat itu memberikan interpretasinya dan ketentuan masingmasing terhadap persyaratan yang berkaitan dengan pernikahan. Mazhab Hanafi, mazhab Mâliki, mazhab Syafi'i dan mazhab Hambali memberikan interpretasi bahwa pernikahan berakibat pada kepemilikan secara sah baik hubungan suami istri maupun hak-hak kebendaan. ${ }^{2}$ Agar terjadi hubungan hak dan kewajiban mereka menentukan keharusan ada mahar yang harus ditunaikan oleh calon mempelai laki-laki Abu Hanifah menentukan mahar harus dibayar maksimal sepuluh dirham, Imâm Malik menentukan empat dirham, Imâm Syafi'i menentukan mahar bisa ditentukan dengan segala sesuatu yang dihargai dalam jual beli, dan Imâm ahmad ibn Hambal berpendapat sama dengan Imâm Syafi i i. ${ }^{3}$

Persyaratan pernikahan menjadi penting pada ulama mazhab adalah adanya wali nikah dan disaksikan dua orang saksi, walaupun dalam mazhab Hanafi tidak mengharuskan adanya wali dan saksi dalam pernikahan karena menurutnya perempuan yang sudah dewasa dan sehat akal bisa menikahkan dirinya sendiri, akan tetapi ulama yang lain dalam mazhab Mâliki dan mazhab Syafi'i wali dan saksi menjadi menjadi syarat sahnya nikah. $^{4}$

Prespektif ulama tentang persyaratan perkawinan tersebut berdampak pada legalitas sekaligus berpengaruh pada hak dan kewajiban, yang menyangkut juga pada akibat hukum terhadap hak-hak kebendaan bagi pasangan suami istri dan anak-anak yang dilahirkan dari perkawinan yang sah. Tulisan ini menggambarkan tentang hak-hak tersebut

2 Muhammad Jawâd al-Mugniyyah, al-Fiqh 'alâ madzâhib al-Khamsah (Beirut: Dâr al-Kitâb al-'`lmiyyah. t.th.), hlm. 364 .

3 Ibid. hlm. 365 .

4 lbid. sesuai dengan hukum Islam yang berlaku di Inonesia.

\section{B. Perkawinan dalam Lintasan Sejarah di Indonesia.}

Hukum perkawinan di Indonesia memiliki sejarah yang panjang, mulai dari sebelum sebelum kedatangan para penjajah yaitu sejak para pedagang Islam tiba di Indonesia, kemudian masa penjajah Belanda dan terakhir masa kemerdekaan. Masa kemerdekaan sendiri terbagi menjadi tiga periode yaitu masa orde lama, masa orde baru, masa reformasi. $^{5}$

Sejak agama Islam datang ke Indonesia selalu ada orang-orang khusus yang ahli dibidang agama Islam yang dipercaya masyarakat Islam pada masa itu untuk mengatasi perselisihan yang muncul di masyarakat muslim, termasuk masalah perkawinan dan perceraian.

Pada awal Islam datang, bentuk-bentuk penyelesaian yang digunakan para pedagang adalah dalam bentuk perdamaian atau disebut juga hakam. Oleh karena itu, lembaga peradilan pertama yang ada di Indonesia pada waktu itu disebut lembaga tahkîm. Setelah masyarakat sudah mulai teratur namun belum memiliki pemerintahan, muncullah lembaga ahl al-hall wa al-'Aqd, yaitu pengangkatan ahli-ahli hukum Islam oleh masyarakat dengan bentuk Peradilan Adat, dimana para hakim/qadi diangkat berdasarkan rapat marga, negeri dan semacamnya. Kemudian diikuti lembaga Peradilan Swapraja yang dibentuk setelah terbentuknya kerajaan-kerajaan Islam di Nusantara. Lalu Peradilan Swapraja berubah menjadi Peradilan Agama. ${ }^{6}$

Sejarah Peradilan Agama, dimulai dari Peradilan Surambi telah ada sejak zaman Sultan Agung di Kerajaan Mataram Yogyakarta. Pada saat itu struktur organisasi diketuai seorang penghulu Hakim dan dibantu 4 orang ulama yang disebut Pathok Nagari. Hukum terapan yang digunakan pada saat itu tidak hanya al-Quran dan sunnah Nabi

5 Khoerudin Nasution, Hukum Perdata Keluarga Islam Indonesia dan Perbandingan Hukum Perkawinan di Dunia Muslim (Yogyakarta: Academia dan Tazzaf. 2007), hlm. 18.

6 Ibid. hlm. 19. 
Muhammad SAW, namun terdapat kitab alMuharrar, al-Mahalî, al-Tuhfah, Fath al-Mu'în, dan Fath al-Wahâb. Selain Peradilan Surambi terdapat juga pada saat itu Peradilan Pradata yang menangani masalah-masalah kriminal.

Daerah-daerah yang penerimaan Islamnya kuat, terdapat Pengadilan Islam yang menggunakan hukum Islam. Hanya saja ada beberapa daerah di Indonesia yang berbeda dengan daerah lain. Beberapa daerah itu yaitu Aceh, Jambi, Kalimantan Selatan dan Timur, Sulawesi Selatan dan tempat-tempat lainnya. Hakim-hakim Islam di di wilayah tersebut diangkat oleh para penguasa setempat. Sedangkan di Jawa hakim-hakim Islam dalam Pengadilan Agama sudah dapat ditemukan di setiap kabupaten sejak kira-kira abad ke-16. ${ }^{8}$

Sebagai bukti-bukti tentang berlaku dan diterimanya hukum Islam oleh umat Islam pada masa itu, dapat dilihat dari bukti-bukti berikut:

1. Statuta Batavia 1642 yang menyebutkan: "Sengketa warisan antara orang pribumi yang beragama Islam harus diselesaikan dengan mempergunakan hukum Islam, yakni hukum yang dipakai oleh rakyat sehari-hari". Munculnya Compendium Freijer sebagai realisasi dari statuta ini;

2. Dipergunakannya kitab al-Muharrar dan Pepakem Cirebon yang terbit tahun 1768, serta peraturan yang dibuat B.J.D Clootwijk untuk daerah Bone dan Goa di Sulawesi Selatan;

3. Di daerah kesultanan Palembang dan Banten juga diterbitkan beberapa kitab hukum Islam yang dijadikan pegangan dalam masalah hukum keluarga dan waris; dan

4. Tanggal 25 Mei 1760 , VOC sebuah perusahaan Belanda, yang ketika itu menjajah

7 Sultan Hamengku Buwono X, Catatan Seorang Raja Tentang Peradilan Agama, dalam Varia Peradilan: Majalah Hukum, Tahun ke-XII, No. 262 September Tahun 2007.

8 Daniel S. Lev, Islamic Courts in Indonesia: a Study of The Political Bases of Legal Institutions (Los Angeles: University of California Press. 1972), hlm. 10 dan 25. Lihat juga Mohammad Atho Mudzhar, FatwaFatwa Majelis Ulama Indonesia: Sebuah Studi tentang Pemikiran Hukum Islam di Indonesia 1975-1988 (Jakarta: Dwibahasa. 1993), hlm. 36.
Indonesia mengeluarkan peraturan senada yang disebut Resolutie der Indische Regeering. Inti dari Resolutie ini adalah mengakui keberadaan dan menggunakan hukum Islam untuk menyelesaikan masalahmasalah yang terjadi di kalangan masyarakat muslim Indonesia dan memberlakukan Compendium Freijer bagi Muslim. ${ }^{9}$

Pada masa penjajahan hukum perkawinan sangat dipengaruhi oleh peran kehidupan beragama masyarakat Indonesia sehugga, masyarakat yang beragama Islam dikuasai oleh hukum Islam (inheren di dalamnya hukum Islam) dan pada umumnya menurut hukum agama perkawinan adalah perbuatan yang suci (sakramen, samskara), yaitu suatu perikatan dua pihak dalam memenuhi perintah dan anjuran Tuhan Yang Maha Esa, agar kehidupan berkeluarga dan berumah tangga serta berkerabat tetangga berjalan baik sesuai dengan ajaran agama masing-masing. Jadi perkawinan dilihat dari segi keagamaan adalah suatu perikatan jasmani dan rohani, yang membawa akibat hukum terhadap agama yang dianut kedua calon mempelai beserta keluarga kerabatnya. Hukum agama telah menetapkan kedudukan manusia dengan iman dan taqwanya, apa yang seharusnya dilakukan dan apa yang tidak seharusnya dilakukan. Oleh karenanya pada dasarnya setiap agama tidak dapat membenarkan perkawinan yang berlangsung tidak seagama. ${ }^{10}$

Menurut hukum Islam perkawinan adalah akad (perikatan) antara wali wanita calon istri dengan pria calon suaminya. Akad nikah itu harus diucapkan oleh wali wanita dengan jelas berupa ijab (serah) dan diterima (kabul) oleh calon suami yang dilaksanakan dihadapan dua orang saksi yang memenuhi syarat.

Menurut hukum Kristen Katolik perkawinan adalah persekutuan hidup antara pria dan wanita atas dasr ikatan cinta kasih yang total dengan persetujuan bebas keduanya yang tidak dapat ditarik kembali.

Menurut hukum Hindu, perkawinan (wiwaha) adalah ikatan antara seorang pria dan wanita sebagai suami istri untuk mengatur

9 Khoerudin Nasution, Hukum Perdata Keluarga. hlm. 19-20.

10 Hilman Hadikusuma, Hukum Perkawinan Indonesia Menurut: Perundangan, Hukum Adat, Hukum Agama (Bandung: Mandar Maju. 2006), hlm. 10. 
hubungan seks yang layak guna mendapatkan keturunan anak pria yang akan menyelamatkan arwah orang tuanya dari neraka Put, yang dilangsungkan dengan upacara ritual menurut agama Hindu Weda Smurti.

Menurut hukum perkawinan Budha (HPAB) keputusan Sangha Agung tanggal 1 Januari 1977 pasal 1 dikatakan perkawinan adalah suatu ikatan lahir batin antara seorang pria sebagai suami dan seorang wanita sebagai istri yang berlandaskan cinta kasih (metta), kasih sayang (karuna) dan rasa sepenanggungan (mudita) dengan tujuan untuk membentuk satu keluarga (rumah tangga) bahagia yang diberkahi oleh Sanghyang Adi Budha/Tuhan Yang Maha Esa, para Budha dan para Budhisatwa-Mahasatwa. Perkawinan adalah sah apabila dilakukan menurut hukum Agama Budha Indonesia.

Dengan aneka ragam masyarakat beragama di Indonesia diberlakukan aneka ragam hukum perkawinan yakni:

1. Burgerlijk Wetboek (Kitab UndangUndang Hukum Perdata). Hukum pernikahan menurut KUHP perdata tercantum dalam Buku Pertama Bab 4 sampai 11, dan berlaku untuk: Golongan Eropa, sebagaimana yang dirumuskan dalam pasal 163 I.S. ayat 2, dengan tidak memandang agama yang dipeluknya, pencatatannya diatur dalam Stbl. 1849 No. 25 dan dilaksanakan dihadapan Pegawai Catatan Sipil. Golongan Timur Asing Cina dengan tidak memandang agama yang dipeluknya, dengan beberapa perubahan yang termuat dalam Stb. 1917 No. 129 yo Stbl. 1924 No. 557, pencatatannya diatur dalam Stlb. 1917 No. 130 yo. Stbl. 1919 No. 81, dilaksanakan dihadapan Pegawai Catatan Sipil; ${ }^{11}$

2. Hukum pernikahan menurut Hukum Adat. Termasuk ke dalam kelompok Hukum Adat, berlaku untuk: Golongan Indonesia asli beragama Islam. Golongan Timur Asing bukan Cina (Arab, Pakistan, India, dan lain-lain) yang beragama Islam. Pencatatannya diatur dengan UndangUndang Nomor 22 Tahun 1946 jo. Undang-Undang Nomor 32 Tahun 1954 dan dilaksanakan oleh Pegawai Pencatat

11 T. Jafizham, Persintuhan Hukum di Indonesia dengan Hukum Perkawinan Islam (Jakarta: PT. Mestika. 2005), hlm. 35.
Nikah pada Kantor Urusan Agama Kecamatan. Golongan Indonesia Asli yang tidak beragama Islam dan bukan umat Masehi yang berdiam di luar daerah Jawa/Madura, Minahasa dan oneraldeling Ambonia, Saparua dan Banda, kecuali pulau Teun, Nila dan Serua; ${ }^{12}$

3. Ordonasi nikah. Ordonasi Nikah Indonesia Umat Kristen di Jawa/Madura, Minahasa dan onderafdeling Ambonia, Saparua dan Banda (Stbl. Tahun 1933 Nomor 74 diubah dengan Stbl. Tahun 1934 Nomor 1934 Nomor 621 dan 1936 Nomor 247). Ordonasi ini berlaku untuk golongan Indonesia asli beragama (Katolik dan Protestan) di Jawa dan Madura, Minahasa Onderaldeling Ambon, Saparua dan Banda, kecuali pulau-pulau Teun, Nila dan Serua. Pencatatanya diatur dalam Stbl. Tahun 1933 Nomor 75 diubah dengan Stbl. Tahun 1933 Nomor 327, 1934 Nomor 621 dan 1936 Nomor 247, dilaksanakan oleh Pegawai Catatan Sipil;

4. Peraturan perkawinan campuran. Peraturan perkawinan campuran berlaku berdasarkan Stbl. Tahun 1898 Nomor 158, ordonasi ini berlaku untuk semua jenis perkawinan campuran; dan

5. Bersikap patuh. Bagi Penduduk Indonesia terbuka ketentuan-ketentuan untuk bersikap patuh pada Hukum Sipil dan Hukum Dagang Eropa seperti yang diatur dalam Stbl. Tahun 1917 Nomor 12 jo. 528, dirubah dan ditambah dengan Stbl. Tahun 1926 Nomor 360, Tahun 1931 Nomor 168 jo. 423, Tahun 1932 Nomor 42, dan Tahun 1939 Nomor 572 jo. 14 dan Bb. 13421. Dengan bersikap patuh pada keseluruhan Hukum perdata yang berlaku untuk orang Eropa. Dengan Demikian mereka patutlah mencatatkan perkawinannya pada Kantor Catatan Sipil. ${ }^{13}$

Pada masa awal kemerdekaan hukum perkawinan yang dipakai umat Islam pada masa awal kemerdekaan adalah:

1. Undang-Undang Nomor 22 Tahun 1946 tentang Pencatatan Nikah, Talak dan Rujuk. Undang-undang Nomor 22 tahun 1946 tentang Pencatatan Nikah, Talak dan

12 Ibid.

13 Ibid. hlm. 37. 
Rujuk ditetapkan oleh Presiden Republik Indonesia pada tanggal 21 Nopember 1946, yang terdiri dari 7 pasal, yang isi ringkasnya sebagai berikut:

a) Pasal 1 ayat 1 s.d. ayat 6, yang isinya diantaranya; Nikah yang dilakukan umat Islam diawasi oleh Pegawai Pencatat Nikah yang diangkat oleh Menteri Agama, Talak dan Rujuk diberitahukan kepada Pegawai pencatat $\mathrm{Ni}$ kah, yang berhak mengadakan pengawasan Nikah, Talak dan Rujuk Pegawai yang ditunjuk Menteri Agama, bila PPN berhalangan dilakukan petugas yang ditunjuk, biaya Nikah, Talak dan Rujuk ditetapkan Menteri Agama;

b) Pasal 2 terdiri dari ayat 1 s.d. 3, yang isinya diantaranya, PPN membuat catatan Nikah, Talak dan Rujuk dan memberikan petikan catatan kepada yang berkepentingan;

c) Pasal 3 terdiri dari 5 ayat, isinya antaranya; sangsi orang yang melakukan nikah, talak dan rujuk yang tidak di bawah Pengawasan PPN, sangsi orang yang melakukan nikah, talak dan rujuk padahal bukan petugas;

d) Pasal 4, isinya hal-hal yang boleh dihukum pada pasal 3 dipandang sebagai pelanggaran;

e) Pasal 5 isinya peraturan yang perlu untuk menjalankan undang-undang ditetapkan oleh Menteri agama;

f) Pasal 6 terdiri 2 ayat, isinya nama undang-undang, dan berlaku untuk daerah luar Jawa dan Madura; dan

g) Pasal 7, isinya undang yang berlaku untuk Jawa dan Madura. ${ }^{14}$

2. Undang-Undang Nomor 32 Tahun 1954 tentang Penetapan Berlakunya UndangUndang Republik Indonesia Tanggal 21 Nopember 1946 Nomor 22 Tahun 1946 tentang pencatatan Nikah, Talak dan Rujuk di Seluruh Daerah Jawa dan Madura. Undang-Undang Nomor. 32 Tahun 1954 disahkan pada tanggal 26 Oktober 1954 oleh Presiden Soekarno. Terdiri dari 3 pasal. ${ }^{15}$

14 Depertemen Agama, Pedoman Pencatatan Nikah (Jakarta: t.pn. 2003), hlm. 73-77.

15 Ibid. hlm. 84-86.
Pada masa kemerdekaan dengan lahirnya Undang-Undang Nomor 1 Tahun 1974 tentang Perkawinan, maka persoalan perdata yang terkait dengan hukum keluarga Islam dapat diakomodir menjadi hukum terapan di Indonesia tentang pelaksanaan perkawinan. Hal tersebut tidak lepas dari momentum sejarah panjang tentang perkawinan di Indonesia, juga disebabkan karena hukum Islam sebagai hukum yang bersifat mandiri telah menjadi satu kenyataan yang hidup dalam masyarakat Indonesia. Bahwa kerajaan-kerajaan Islam yang berdiri di Indonesia telah melaksanakan Hukum Islam dalam kekuasaannya masing-masing.

Bukti sejarah yang mempengaruhi lahirnya Undang-Undang nomor 1 Tahun 1974 diawali pada abad ke-13 M, Kerajaan Samudra Pasai di Aceh Utara menganut hukum Islam yang bermazhab Syafi ${ }^{i}$, kemudian pada abad ke 15 dan $16 \mathrm{M}$ di pantai utara jawa, terdapat kerajaan Islam, seperti Kerajaan Demak, Jepara, Tuban, Gresik dan Ngampel. ${ }^{16}$ Fungsi memelihara agama ditugaskan kepada penghulu dengan para pegawainya yang bertugas melayani kebutuhan masyarakat dalam bidang peribadatan dan segala urusan yang termasuk dalam hukum keluarga/perkawinan, sementara itu, di bagian timur Indonesia berdiri pula kerajaan-kerajaan Islam seperti Gowa, Ternate, Bima dan lain-lain. Masyarakat Islam di wilayah tersebut diperkirakan juga menganut hukum Islam mazhab Syafi'i. ${ }^{17}$

Pada masa kedatangan Verenigde Oost Indische Compagnie (VOC) di Indonesia, kedudukan hukum (keluarga) Islam telah ada di masyarakat sehingga pada saat itu diakui sepenuhnya oleh penguasa VOC. Pada masa pemerintahan Belanda di Indonesia, Belanda menghimpun hukum Islam yang disebut dengan Compendium Freiyer, mengikuti nama penghimpunnya. Kemudian membuat kumpulan hukum perkawinan dan kewarisan Islam untuk daerah Cirebon, Semarang, dan Makassar (Bone dan Gowa). Ketika pemerintahan VOC berakhir, politik penguasa kolonial berangsur-angsur berubah terhadap hukum Islam. Pada Konggres Perempuan Indo-

16 Hamka, Sejarah Umat Islam (Jakarta: Bulan Bintang. 1976), Jilid II, hlm. 53.

17 lbid. hlm. 144-145. 
nesia I pada tanggal 22-25 Desember $1928 \mathrm{di}$ Yokyakarta mengusulkan kepada Pemerintah Belanda agar segera disusun undangundang perkawinan, namun mengalami hambatan dan mengganggu kekompakan dalam mengusir penjajah. ${ }^{18}$

Pada permulaan tahun 1937 Pemerintahan Hindia Belanda menyusun rencana pendahuluan Ordonansi Perkawinan tercatat (onwerpordonnantie op de ingeschrevern huwelijken) dengan pokok-pokok isinya sebagai berikut: Perkawinan berdasarkan asas monogami dan perkawinan bubar karena salah satu pihak meninggal atau menghilang selama dua tahun serta perceraian yang diputuskan oleh hakim. ${ }^{19}$ Menurut rencana rancangan ordonansi tersebut hanya diperuntukkan bagi golongan orang Indonesia yang beragama Islam dan yang beragama Hindu, Budha, Animis. Namun rancangan ordonansi tersebut di tolak oleh organisasi Islam karena isi ordonansi mengandung hal-hal yang bertentangan dengan hukum Islam.

Setelah kemerdekaan, Pemerintah RI berusaha melakukan upaya perbaikan di bidang perkawinan dan keluarga melalui penetapan UU Nomor 22 Tahun 1946 mengenai Pencatatan Nikah, Talak dan Rujuk bagi masyarakat beragama Islam. Dalam pelaksanaan undangundang tersebut diterbitkan Instruksi Menteri Agama Nomor 4 Tahun 1946 yang ditujukan untuk Pegawai Pencatat Nikah (PPN). Instruksi tersebut selain berisi tentang pelaksanaan UU Nomor 22 Tahun 1947 juga berisi tentang keharusan PPN berusaha mencegah perkawinan anak yang belum cukup umur, menerangkan kewajiban-kewajiban suami yang berpoligami, mengusahakan perdamaian bagi pasangan yang bermasalah, menjelaskan bekas suami terhadap bekas istri dan anak-anaknya apabila terpaksa bercerai, selama masa idah agar PPN mengusahakan pasangan yang bercerai untuk rujuk kembali. ${ }^{20}$

Pada bulan Agustus 1950, front wanita dalam parlemen, mendesak agar pemerintah meninjau kembali peraturan perkawinan dan

18 Arso Sosroatmodjo dan A. Wait Aulawi, Hukum Perkawinan di Indonesia (Jakarta: Bulan Bintang. 1975), hlm. 11.

19 Nani Suwondo, Kedudukan Wanita Indonesia dalam Hukum dan Masyarakat (Jakarta: Ghalia Indonesia. 1992), hlm. 77.

${ }_{20}$ Ibid. hlm. 78-79. menyusun rencana undang-undang perkawinan. Maka akhirnya Menteri Agama membentuk Panitia Penyelidikan Peraturan Hukum Perkawinan, Talak dan Rujuk. Maka lahirlah Peraturan Pemerintah (PP) Nomor 19 Tahun 1952 yang memungkinkan pemberian tunjangan pensiun bagi istri kedua, ketiga dan seterusnya. ${ }^{21}$

Tanggal 6 Mei 1961, Menteri Kehakiman membentuk Lembaga Pembinaan Hukum Nasional yang secara mendalam mengajukan konsep RUU Perkawinan, sehingga pada tanggal 28 Mei 1962 Lembaga hukum ini mengeluarkan rekomendasi tentang asas-asas yang harus dijadikan prinsip dasar hukum perkawinan di Indonesia. Kemudian diseminarkan oleh lembaga hukum tersebut pada tahun 1963 bekerjasama dengan Persatuan Sarjana Hukum Indonesia bahwa pada dasarnya perkawinan di Indonesia adalah perkawinan monogami namun masih dimungkinkan adanya perkawinan poligami dengan syarat-syarat tertentu. Serta merekomendasikan batas minimum usia calon pengantin. ${ }^{22}$

Pada tahun 1973 Fraksi Katolik di Parlemen menolak rancangan UU Perkawinan yang berdasarkan Islam. Konsep RUU Perkawinan khusus umat Islam yang disusun pada tahun 1967 dan rancangan 1968 yang berfungsi sebagai Rancangan Undang-Undang Pokok Perkawinan yang di dalamnya mencakup materi yang diatur dalam Rancangan tahun 1967. Akhirnya Pemerintah menarik kembali kedua rancangan dan mengajukan RUU Perkawinan yang baru pada tahun 1973..$^{23}$ Pada tanggal 22 Desember 1973, Menteri Agama mewakili Pemerintah membawa konsep RUU Perkawinan yang disetujui DPR menjadi Undang-Undang Perkawinan. Maka pada tanggal 2 Januari 1974, Presiden mengesahkan undang-undang tersebut dan di-

21 Indriaswari Dyah Saptaningrum, Sejarah UU Nomor 1 Tahun 1974 tentang Perkawinan dan Pembakuan Peran Gender, dalam Perspektif Perempuan (Jakarta: Lembaga Bantuan Hukum Asosiasi Perempuan untuk Keadilan. 2000), hlm. 53.

22 R. Soetedjo Prawirohamidjojo, Pluralisme dalam Perundang-Undangan Perkawinan di Indonesia (Surabaya: Universitas Airlangga Press. 1988), hlm. 18.

23 Deliar Noer, Administrasi Islam di Indonesia (Jakarta: Rajawali Pers. 1983), hlm. 98. 
undangkan dalam Lembaran Negara Nomor 1 tahun 1974 tanggal 2 Januari 1974.

\section{Perkawinan Tidak Dicatat}

Kawin dalam bahasa Arab dikenal dengan kata nikah atau tazwij dan kata ini di dalam al-Quran terdapat dalam 20 ayat termasuk kata deviasinya, sedangkan nakaha dan kata deviasinya terdapat 17 ayat di dalam al-Quran. Kata nikah menurut al-Jazîrî memiliki beberapa pengertian, secara etimologi dikenal dengan al-wathi, persetubuhan dan aldlamman, menyatu. Kata ini yang kemudian dikalangan ulama fikih terjadi perbedaan pendapat, apakah nikah dalam pengertian hakikat adalah akad atau bersetubuh. ${ }^{24}$ Menurut al-Karkhî nikah adalah ikatan perkawinan bukan persetubuhan, dengan demikian bahwa sama sekali tidak pernah disebutkan dalam al-Quran kata nikah dengan arti wathi karena didalam al-Quran menggunakan kinayah dan penggunaan kata kinayah tersebut gaya bahasa yang halus. ${ }^{25}$

Secara istilah syara' ada beberapa definisi ulama fikih tapi esensi yang terdapat dalam definisi tersebut hampir sama. Mazhab Syafi'i mengatakan akad yang mengandung kebolehan melakukan hubungan suami istri dengan lafal nikah atau yang semakna dengan itu, sedangkan menurut mazhab Hanafi nikah merupakan akad yang memfaidahkan halalnya melakukan hubungan suami istri antara seorang suami dan istri selama tidak ada halangan syara. ${ }^{26}$ Jumhur ulama menekankan pentingnya menyebutkan lafal yang digunakan dalam akad nikah tersebut yakni lafal nikah, kawin atau yang selafal dengan itu.

Dalam Undang-Undang Nomor 1 Tahun 1974 pasal 1 menyebutkan bahwa; Perkawinan adalah ikatan lahir batin antara seorang pria dengan seorang wanita sebagai suami istri dengan membentuk keluarga yang bahagia dan kekal berdasarkan Ketuhanan

24 Al-Syaybanî, Ikhtilâf al-'Ammah al-'Ulamâ' (Jakarta: Dâr al-Kutûb al-'Ilmiyyah. t.th.), hlm. 120.

25 Muhammad 'Alî al-Shâbûnî, Rawâ'i' al-Bayân: Tafsîr âyât al-Ahkâm (Beirut: Dâr al-Fikr. t.th.), hlm. 285.

26 Muhammad Abû Zahrah, al-Ahwâl al-Syakhshiyyah (Beirut: Dâr al-Fikr. 1950), hlm. 17.
Yang Maha Esa. ${ }^{27}$ Pada pasal 2 ayat (1) Perkawinan adalah sah apabila dilakukan menurut hukum masing-masing agama dan kepercayaannya itu, ayat (2) menyatakan Tiap-tiap perkawinan dicatat menurut peraturan perundang-undangan yang berlaku. Juga dipahami secara gramatikal maka antara pasal 1 dan pasal 2 memiliki hubungan yang saling berkaitan, artinya perkawinan yang bertujuan membentuk keluarga bahagia itu adalah perkawinan yang dilakukan berdasarkan hukum agama dan kepercayaan dan perkawinan yang di dicatat.

Kata sirri berasal dari bahasa Arab yang bermakna diam-diam atau rahasia lawan dari kata 'alaniyyah yaitu terang-terangan. Kata sirri dijadikan kata majemuk dengan kata nikah, sehingga menjadi nikah sirri untuk menyebutkan bahwa nikah yang dilakukan secara diam-diam tersembunyi atau tidak tercatat di lembaga Negara. Nikah sirri dalam paradigma sekarang adalah tema yang digunakan untuk menyebut pernikahan yang dilakukan bukan di depan Pegawai Pencatat Nikah dalam hal ini KUA, sehingga pernikahan tersebut tidak tercatat di Kantor Urusan Agama.

Istilah nikah sirri atau nikah yang dirahasiakan memang sudah dikenal dikalangan ulama yaitu pernikahan yang memenuhi unsur-unsur atau rukun-rukun dan syaratsyarat pernikahan menurut hukum Islam, yaitu adanya mempelai laki-laki dan perempuan, ada ijab qabul ada wali nikah dan ada dua orang saksi, hanya saja saksi diminta untuk merahasiakan atau tidak memberitahukan terjadinya pernikahan tersebut kepada khalayak ramai, dengan sendirinya tidak ada walimat al-'ursy atau dalam bentuk yang lain. ${ }^{28}$

Dikalangan ulama mazhab, nikah sirri dikenal ketika membicarakan tenang rukun nikah yaitu saksi nikah, mereka sepakat bahwa

27 Anonimous, Undang-Undang Nomor 7 Tahun 1989 tentang Peradilan Agama dilengkapi UndangUndang RI Nomor 14 Tahun 1970, Undang-Undang RI Nomor 14 Tahun 1985, Undang-UNdang RI Nomor 1 Tahun 1974, hlm. 266.

28 Muhammad Ra'fat 'Utsmân, 'Aqd al-Zawwâj: Arkânuhû wa Syurûthu Shihatihî fî al-Fiqh al-Islâmî (t.t.: t.pn. t.th.), hlm. 299. 
keberadaan saksi merupakan salah satu yang harus ada dalam perkawinan sehingga perkawinan tidak sah jika tidak ada saksi. ${ }^{29}$ Namun keberadaan saksi terjadi perdebatan dikalangan ulama fikih mengingat hadits yang dijadikan sumber hukum tersebut diperdebatkan validitasnya. Dua hadits riwayat "Aisyah yang

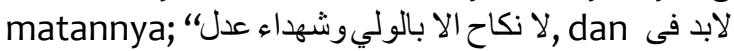
البغين Kemudian hadits dari Ibn “Abbas: " البغي: التي ينكهنا انفسهن " Kedua hadits tersebut dinilai dla'if tetapi satu sama lain saling menguatkan, dari sini ulama fikih berbeda pendapat.

Menurut Hanafiyyah, Syafi'iyyah dan pendapat yang masyhur dari Imâm Ahmad ibn Hanbal, golongan Ibadiyah Khawarij, 'Umar, 'Alî ibn Abî Thâlib, Ibn 'Abbas Sayyid ibn Musayyab, Jâbir ibn Zayd, al-Hasân, alNakha'î, Qatadah, al-Tsawrî dan al-Auzâ‘î mengatakan bahwa nikah tidak sah tanpa kehadiran dua orang saksi. Sedangkan berdasarkan riwayat dari Imâm Ahmad, Ibn 'Umar alHasân ibn 'Alî, Ibn Zubayr, Salim, Ibn 'Abdullah ibn 'Umar dan sebagian dari kalangan Syi'ah Imâmiyyah menyatakan bahwa nikah tanpa saksi hukumnya sah selama calon mempelai telah balig dan cerdas (rusyd). Sementara menurut pendapat Mâlikiyyah kesaksian dalam pernikahan adalah wajib sekalipun ketika akad tidak mesti dihadiri saksi. ${ }^{30}$

Pernikahan sirri sering juga diartikan oleh masyarakat umum dengan; Pertama, pernikahan tanpa wali. Pernikahan semacam ini dilakukan secara rahasia (sirri) dikarenakan pihak wali perempuan tidak setuju; atau karena menganggap absah pernikahan tanpa wali; atau hanya karena ingin memuaskan nafsu syahwat belaka tanpa mengindahkan lagi ketentuan-ketentuan syariat; kedua, pernikahan yang sah secara agama namun tidak dicatatkan dalam lembaga pencatatan negara. Pandangan ini sejalan dengan apa yang diungkapkan oleh Ahmad Sabiq ibn 'Abd alLathîf Abû Yûsuf. ${ }^{31}$

Adapun mengenai fakta pertama, yakni pernikahan tanpa wali; sesungguhnya Islam

29 Wahbah al-Zuhaylî, Fiqh al-Islamî wa Adillatuh. hlm. 70-71.

30 Ibid. hlm. 72.

31 http://www.mail-archive.com/belajar-Islam @yahoogroup.com/msgo0228.html, diakses tanggal 29 September 2014. telah melarang seorang wanita menikah tanpa wali. Ketentuan semacam ini didasarkan pada sebuah hadits yang dituturkan dari sahabat Abû Mûsâ r.a.; bahwasanya Rasulullah SAW bersabda:

$$
\text { لا نكاح الا بالولي }
$$

Tidak sah suatu pernikahan tanpa seorang wali. (HR. yang lima kecuali Imâm al- Nasâ̂î)

Berdasarkan dalâlah al-iqtidlâ", kata "lâ" pada hadits menunjukkan pengertian 'tidak sah', bukan sekedar 'tidak sempurna' sebagaimana pendapat sebagian ahli fikih. Makna semacam ini dipertegas dan diperkuat oleh hadits yang diriwayatkan oleh Aisyah ra, bahwasanya Rasulullah SAW pernah bersabda: Artinya, "Wanita mana pun yang menikah tanpa mendapat izin walinya, maka pernikahannya batil; pernikahannya batil; pernikahannya batil".32 (HR. yang lima kecuali Imâm al- Nasâ'î)

Berdasarkan hadits-hadits di atas dapat rumuskan bahwa pernikahan tanpa wali adalah pernikahan batil. Pelakunya telah melakukan maksiyat kepada Allah SWT, dan berhak mendapatkan sanksi di dunia. Banyak faktor yang menyebabkan seseorang tidak mencatatkan pernikahannya di lembaga pencatatan sipil negara. ${ }^{33}$ Pertama, karena faktor biaya, alias tidak mampu membayar administrasi pencatatan; Kedua, yang karena sebab takut ketahuan melanggar aturan yang melarang pegawai negeri nikah lebih dari satu, dan lain sebagainya; Ketiga, karena faktor geografis yang jauh dari tempat pencatatan pernikahan sehingga menyulitkan bahkan mungkin biaya menuju ke KUA lebih besar dari biaya pernikahan itu sendiri; dan Keempat, pernikahan yang dirahasiakan karena pertimbangan-pertimbangan tertentu, misalnya karena takut mendapatkan stigma negatif dari masyarakat yang terlanjur menganggap tabu pernikahan sirri, atau karena pertimbangan-pertimbangan rumit yang memaksa seseorang untuk merahasiakan pernikahannya, misalnya karena alasan bagi laki-

32 Imâm al-Syawkanî, Nayl al-Awthâr. hlm. 230.

33 Lihat Undang-Undang Perkawinan Nonor 1 Tahun 1974 pasal 4 dan Pasal 5 mengenai izin poligami oleh Pengadilan Agama dan syarat-syarat poligami. 
laki yang ingin berpoligami merasa keberatan dengan syarat-syarat poligami yang diatur dalam undang-undang, karena secara psikologis sulit diharapkan dari istri atau istri-istri bermurah hati memberikan persetujuan kepada suami untuk melakukan poligami.

\section{Akibat Hukum Perkawinan Tidak Dica- tat Terhadap Hak Kebendaan Bagi Istri dan Anak.}

Perkawinan merupakan perbuatan hukum yang berakibat pada sah tidaknya suatu hubungan antara seorang laki-laki dan perempuan, sahnya sebuah perkawinan akan berdampak pada akibat hukum setelah terjadinya penkawinan. Sahnya perkawinan dalam Undang-undang Nomor 1 Tahun 1974 terdapat dalam pasal 2 ayat (1) yang menjelaskan, bahwa: "perkawinan adalah sah apabila dilakukan menurut hukum masing-masing agamanya dan kepercayaannya itu". Dapat dipahami dari kalimat tersebut bahwa Undang-undang Nomor 1 Tahun 1974 menghendaki sahnya sebuah perkawinan jika ada dua hal yang terpenuhi yakni syarat sesuai dengan ketentuan agamanya masing-masing dan prosedur yang dikehendaki oleh undangundang negara tanpa memperhatikan ketentuan tersebut perkawinan tersebut tidak sah.

Campur tangan pemerintah dalam pengaturan pernikahan merupakan kewenangannya dalam rangka menjaga ketertiban umum itulah sebabnya diatur menyangkut proses administrasi yakni perkawinan harus dicatat sebagaimana termuat dalam pasal 2 ayat (2) Undang-Undang Nomor 1 Tahun 1974, bahwa: "Tiap-tiap perkawinan dicatat menurut peraturan perundang-undangan yang berlaku". Kedua pasal dalam undangundang tersebut di atas mengandung pemahaman bahwa apabila perkawinan dilaksanakan hamya secara "agama saja" dan tidak dicatatkan pada instansi yang berwenang dalam hal ini di Kantor Catatan Sipil bagi mereka yang beragama bukan Islam dan di Kantor Urusan Agama bagi mereka yang beragama Islam sebagaimana yang diatur dalam Undang-Undang Nomor 32 Tahun 1954 tentang Penetapan Berlakunya UndangUndang Republik Indonesia Nomor 22 Tahun 1956 tentang Pencatatan Nikah, Talak dan Rujuk di Seluruh Daerah Luar Jawa dan Ma- dura, maka perkawinan tersebut tidak sah dan tidak mempunyai kekuatan hukum, hal ini karena pasal 2 ayat (1) dan ayat (2) Undang-Undang Nomor 1 Tahun 1974 merupakan satu kesatuan yang tidak dapat dipisahkan sebagai syarat sahnya perkawinan. Hal ini juga dijelaskan dalam Kompilasi Hukum Islam pasal 4 bahwa: "Perkawinan adalah sah apabila dilakukan menurut hukum Islam sesuai dengaan Pasal 2 ayat (1) Undang-Undang Nomor 1 Tahun 1974 tentang Perkawinan. Kompilsi Hukum Islam juga mempertegas bahwa perkawinan yang sah tidak hanya dilakukan menurut hukum agama akan tetapi juga sesuai dengan undangundang yang mengatur tentang perkawinan dalam suatu negara.

Pencatatan perkawinan tersebut memberikan perlindungan hukum tidak saja bagi mereka yang melangsungkan perkawinan, tetapi pada anak-anak mereka dan harta kekayaan yang diperoleh setelah terjadinya perkawinan sampai putusnya perkawinan apakah putus akibat perceraian atau kematian. Adapun proses pencatatan perkawinan yang diatur dalam peraturan pemerintah Nomor 9 Tahun 1975 antara lain:

1. Pasal 4 dan 5 PP Nomor 9 Tahun 1975;

2. Pasal 6, 7, 8 dan 9 PP Nomor 9 Tahun 1975;

3. Pasal 12 dan 13 PP Nomor 9 Tahun 1975; dan

4. Untuk memberikan kepastian hukum kepada kedua mempelai masing-masing diserahkan kutipan akta perkawinan sebagai bukti autentik atas peristiwa hukum tersebut. ${ }^{34}$

Bagi yang beragama Islam tentang tata cara perkawinan dimuat dalam Kompilasi Hukum Islam pasal 5 ayat (1) dan (2) pasal 6 ayat (1) dan (2) dan pasal 7 ayat (1), (2), dan (3) yaitu:

1. Agar terjamin ketertiban perkawinan bagi masyarakat Islam setiap perkawinan harus dicatat;

2. Pencatatan perkawinan tersebut dilakukan oleh Pegawai Pencatat Nikah.

3. Untuk memenuhi ketentuan tersebut diatas maka perkawinan harus dilangsung-

34 Abdurrahman, Himpunan Peraturan Perundangundangan tentang Perkawinan (Jakarta: Akademika Pressindo. Jakarta, 1986), hlm. 92-93. 
kan dihadapan dan dibawah pengawasan Pegawai Pencatat Nikah;

4. Perkawinan yang dilakukan di luar pengawasan Pegawai Pencatat Nikah tidak mempunyai kekuatan hukum; dan

5. Perkawinan hanya dapat dibuktikan dengan akta nikah yang dibuat oleh Pegawai Pencatat Nikah.

Pencatatan perkawinan dan tatacara pelaksanaannya merupakan aturan tambahan atau istilah Satria Effendi menyebutnya dengan peraturan yang bersifat tawsiqî, ${ }^{35}$ dengan tujuan agar pernikahan dikalangan umat Islam tidak liar tetapi tercatat dengan memakai surat Akta Nikah secara resmi dikeluarkan oleh pihak yang berwenang dan secara administratif ada peraturan yang mengharuskan agar suatu pernikahan dicatat menurut perundang-undangan yang berlaku.

Aspek lain, dengan adanya pencatatan perkawinan bertujuan agar sebuah lembaga perkawinan yang mempunyai tempat yang strategis dalam masyarakat Islam bisa dilindungi dari upaya-upaya negatif dari pihakpihak yang tidak bertanggung jawab, misalnya antisipasi dari adanya pengingkaran akad nikah dari pihak suami istri dikemudian hari, maka salah satu pihak bisa melakukan upaya hukum untuk memperoleh haknya masingmasing karena adanya bukti autentik yang menguatkan pernah terjadinya perkawinan.

Dinegara Republik Arab, Mesir misalnya, yang memiliki Undang-undang Perkawinan lebih dahulu dari Indonesia misalnya dalam Undang-undang Nomor 78 Tahun 1931 menyebutkan; tidak akan didengar suatu pengaduan tentang perkawinan atau tentang halhal yang menyangkut perkawinan kecuali atas dasar adanya pencatatan akad nikah atau adanya dokumen resmi pernikahan. ${ }^{36}$ Minimal ada lima hukum keluarga yang mencantumkan ketentuan tentang masalah pencatatan perkawinan dalam hukum keluarga muslim yakni Indonesia, Iran, Yaman Selatan, Yordania, dan Srilangka. Bahkan di negaranegara tersebut mencantumkan sanksi hukuman terhadap petugas yang melakukan

35 Satria Effendi, Problematika Hukum Keluarga Kontemporer (Jakarta: Balitbang Depag RI. 2004), hlm. 34.

36 Ibid. pencatatan pernikahan diluar izin pengadilan.

Di Iran perkawinan yang dilakukan tanpa registrasi pihak yang bersangkutan diancam hukuman penjara 1 sampai dengan 6 bulan, di Yaman memberlakukan hukuman denda maksimal 200 dinar atau penjara maksimal 2 tahun atau kedua hukuman tersebut sekaligus terhadap semua pelaku atau para pihak yang melakukan perkawinan tanpa registrasi, di Yordania, para pihak yang melakukan, pihak pelaksana dan para saksi terkait perkawinan yang tak terdaftar atau tanpa registrasi pihak yang berwenang dapat dikanakan hukuman penjara berdasarkan ketentuan Jordania Penal Code (UU Hukum Pidana Yordania) dan denda maksimal 1000 dinar. ${ }^{37}$

Yang menarik perhatian justru di Srilanka yang penduduk muslimnya bukan mayoritas, justru lebih banyak memasukkan aturan kriminalisasi dalam hukum keluarga muslim yang diberlakukan disana, hal tersebut tercermin dalam ketentuan-ketentuan sebagai berikut:

1. Membuat data palsu pada pencatatan, buku izin, dokumen, salinan atau copy sekitar perkawinan dan perceraian dapat dikenakan hukuman penjara maksimal 3 tahun penjara;

2. Melanggar ketentuan dalam undangundang perkawinan mereka pada pasal 81 dijelaskan bahwa:

a) Mempelai pria, petugas pencatat yang lalai atau enggan mencatatkan pernikahannya, atau lalai enggan melaksanakan tugas pencatatan pernikahan;

b) Siapa saja yang mendukung atau membantu seorang laki-laki muslim untuk memperoleh atau mempengaruhi atau mendaftarkan suatu perceraian di luar atau tidak sesuai dengan ketentuan UU ini atau bersekongkol melanggar melalui cara lain; dan

c) Qadlî, petugas pencatatan, dan pihak yang turut andil atau berpatrisipasi melanggar berbagai aturan tentang

37 Nasaruddin Umar, Hukum Keluarga Kontemporer di Negara-Negara Muslim, Makalah disampaikan dalam acara Seminar Nasional Hukum Materil Peradilan Agama, antara Cita, Realita dan Harapan, Hotel Red Top, Jakarta 19 Pebruari 2010, hlm. 8. 
mengizinkan orang lain untuk menempati posisi mereka dan menjaga semua buku, dokumen berkas yang terkait daftar suatu perkawinan atau perceraian orang muslim atau rekaman berita acara mengenai perceraian yang diakibatkan atau mengaku diakibatkan pihak lain. Mereka di atas akan dijatuhi hukuman untuk pertama kalinya maksimal 100 rupee, sedangkan hukuman kedua kalinya maksimal 100 rupee atau penjara maksimal 6 bulan atau keduanya sekaligus yakni denda dan penjara.

3. Petugas yang sengaja melakukan pencatatan dan pihak lain yang mendukung atau membantu pencatatan atau suatu perkawinan yang bertentangan dengan aturan hukum yang berlaku dapat dijatuhi hukuman denda maksimal 100 rupee atau penjara maksimal 6 bulan penjara atau keduanya sekaligus;

4. Setiap pihak bukan seorang hakim yang mengeluarkan atau menyatakan untuk mengeluarkan izin atau daftar/catatan sebuah perceraian berdasarkan undangundang yang berlaku atau pihak yang bukan petugas pencatatan, melakukan pencatatan atau menyatakan akan mencatat suatu perkawinan berdasarkan undangundang yang berlaku dijatuhi denda 100 rupee atau hukuman penjara 6 bulan atau keduanya sekaligus;

5. Setiap pihak yang sengaja atau mengetahui membuat keterangan palsu dalam suatu pernyataan yang ditandatanganinya tentang pengisian dan penandatanganan formulir registrasi perkawinan oleh pasangan pengantin dan wali pihak perempuan dikenakan denda 100 rupee atau penjara maksimal 6 bulan atau keduanya sekaligus; dan

6. Setiap petugas pencatatan:

a) Lalai atau menolak tanpa sebab/alasan yang sah melakukan pencatatan perkawinan;

b) Kecuali dalam kasus yang melakukan pencatatan suatu perkawinan yang diadakan diluar wilayah tugasnya;

c) Melakukan pencatatan suatu perkawinan yang melanggar kondisi-kondisi atau batasan yang terdapat pada surat tugasnya;

d) Mencatat perkawinan yang tidak dihadirinya;

e) Sengaja menolak untuk melaksanakan atau yang terkait dengan pencatatan perkawinan sebagai kewajiban yang dibebankan kepadanya; dan

f) Sengaja melanggar atau menentang berbagai aturan dalam undang-undang yang berlaku dapat dikenakan hukuman denda sebesar 100 rupee. ${ }^{38}$

Akibat hukum perkawinan tidak dicatat walau secara hukum telah memenuhi syarat syar $^{\text {i }} \mathrm{i}^{39}$ maksudnya syarat dimana keabsahan suatu ibadah atau akad tergantung kepadanya, misalnya adanya kedua mempelai yang telah memenuhi syarat nikah, ada wali, ada dua orang saksi dan adanya ijab dan qabul, akan tetapi perkawinan yang dilakukan di luar pengetahuan dan pengawasan Pegawai Pencatat Nikah tidak memiliki kekuatan hukum yang tetap sehingga dimata hukum negara dianggap tidak sah hal ini sangat berdampak pada istri dan perempuan pada umumnya baik secara hukum maupun sosial bahkan akibat hukum dari anak yang dilahirkan dari perkawinan yang tidak dicatat termasuk juga tidak diakui dalam bembagian harta gonogini dan waris ketika salah satu pihak meninggal dunia. Hal ini karena dimata hukum perkawinan dianggap tidak pernah terjadi, dan status sosial yang melekat pada istri yang dinikahi tanpa dicatat sering disimbolkan sebagai istri simpanan.

Dalam Undang-Undang Perkawinan Nomor 1 Tahun 1974 pasal 42 dijelaskan bahwa: "Anak yang sah adalah anak yang dilahirkan dalam atau akibat perkawinan yang sah, pasal 43 ayat (1), menjelaskan bahwa; "Anak yang lahir di luar perkawinan hanya mempunyai hubungan perdata dengan ibunya dan keluarga ibunya". Ada dua pemahaman ter-

38 lbid. hlm. 9.

39 Syarat syar'i merupakan istilah yang dikemukakan Wahbah Zuhaylî dalam buku al-Fiqh al-Islâm wa Adillatuhu yang dikutip oleh Satria Effendi, syarat tersebut diiringi dengan syrat taswiqy yaitru syarat yang dirumuskan untuk dijadikan sebagai bukti kebenaran terjadinya suatu tindakan hukum sebagai upaya antisipasi adanya ketidak jelasan dikemudian hari. 
hadap pasal 43 ayat (1) tersebut, yang dimaksudkan di luar perkawinan yang sah bisa dikatagorkan anak tersebut lahir tanpa adanya perkawinan dan bisa dikatagorikan anak tersebut lahir karena perkawinan kedua orang tuanya tidak dicatat.

Tujuan pasal dalam undang-undang tersebut untuk memberikan perlindungan perdata dan kepastian hukum terhadap hubungan hukum keperdataan antara anak dan ibunya serta keluarga ibunya karena perkawinan yang tidak dicatat dapat diartikan sebagai peristiwa perkawinan yang tidak ada sehingga anak yang dilahirkan yang tidak dicatat menurut undang-undang dikatagorikan sebagai anak yang lahir dari perkawinan yang sah.

Perkawinan tidak saja mempunyai akibat hukum terhadap diri pribadi mereka yang melangsungkan pernikahan dan terhadap anakanak yang dilahirkan akibat perkawinan tersebut akan tetapi memiliki akibat hukum terhadap harta suami istri, hubungan hukum kekeluargaan dan kekayaan sangat erat kaitannya satu sama lainnya. Hubungan hukum dalam kekeluargaan menentukan hubungan hukum dalam dalam harta perkawinan tidak lain, merupakan hukum kekayaan keluarga. ${ }^{40}$

Dalam setiap perkawinan harta kekayaan yang dimiliki suami istri baik diperoleh sebelum terjadinya perkawinan atau sesudah terjadinya perkawinan yang dikenal dengan harta bawaan dan harta bersama dapat diperhitungkan sebagai hak yang dapat dipergunakan untuk kepentingan rumah tangganya dengan persetujuan kedua belah pihak, sekalipun dalam harta bawaan masing-masing berhak mengusai sepanjang para pihak tidak menentukan lain. Dalam hukum Islam masing-masing suami istri berhak memiliki harta secara perorangan dalam batas yang dikuasainya dan tidak dapat diganggu oleh pihak lain misalnya suami istri menerima warisan, hibah atau wasiat tanpa ikut sertanya pihak lain, dan harta bawaan tersebut menjadi hak masing-masing baik suami maupun istri. ${ }^{41}$

40 J. Satrio, Hukum Harta Perkawinan (Bandung: Citra Adytia Bakti. 1991), hlm. 5.

41 Ahmad Azhar Basyir, Hukum Perkawinan Islam (Yogyakarta: Fakultas Hukum UII. 1996), hlm. 61.
Jika merujuk pada pasal 42 dan pasal 43 ayat (1) Undang-undang perkawinan di atas maka secara tegas hanya ada hubungan hukum perdata dengan ibunya sehingga akibat hukum yang lebih jauh dalam hak kebendaan dalam perkawinan seperti yang diatur dalam pasal 65 ayat (1) poin c yang mengatakan "Istri mempunyai hak yang sama atas harta bersama yang terjadi sejak berlangsungnya perkawinan", perkawinan yang dimaksud dalam pasal tersebut adalah perkawinan yang diatur menurut undang-undang yang berlaku. Lebih lanjut dalam Kompilasi Hukum Islam tentang pengaturan harta kekayaan terdapat dalam pasal 85, 86, 87, 88, 89, 90, 91, 92, 93, 94, 95, 96 dan pasal 97. Perkawinan yang tidak dicatat berdampak pada hilangnya hak tuntutan atas harta bersama jika perkawinan tersebut putus baik karena perceraian atau karena kematian, hak menuntut nafkah ataupun harta waris ketika salah satu pihak meninggal dunia, harta bersama yang diperoleh akibat perkawinan yang tidak dicatat hanya dikuasai oleh masing-masing yang menghasilkannya karena tidak ada harta gonogini atau harta bersama yang dihasilkannya dari pernikahan yang sah.

\section{E. Isbat Nikah sebagai Upaya Hukum}

Ketentuan yang mengatur perkawinan umat Islam di Indonesia di samping ada ketentuan tentang perundang-undangan yang mengharuskan pencatatan nikah sehingga dengan hal itu nikah akan dapat akta nikah secara resmi maka ada ketentuan lain yang mengatur tentang isbat nikah yaitu; merupakan upaya hukum yang dapat dilakukan untuk dapat pengakuan negara bagi perkawinan yang tidak dicatat melalui pengajuan penetapan nikah. Dalam pasal 7 ayat (2) Kompilasi Hukum Islam dinyatakan bahwa; "Dalam hal perkawinan tidak dapat dibuktikan dengan akta nikah, dapat di ajukan isbat nikahnya ke Pengadilan Agama" dan pada ayat (3) nya disebutkan: "Isbat nikah yang dapat diajukan ke Pengadilan Agama terbatas mengenai hal-hal yang berkenaan dengan:

1. Adanya perkawinan dalam rangka penyelesaian perkawinan;

2. Hilangnya akta nikah;

3. Adanya keraguan tentang sah atau tidaknya salah satu syarat perkawinan; 
4. Adanya perkawinan yang dilakukan sebelum berlakunya Undang-undang nomor 1 tahun 1974; dan

5. Perkawinan yang dilakukan oleh mereka yang tidak mempunyai halangan perkawinan menurut Undang-undang nomor 1 tahun 1974.

Dalam pasal 4 Kompilasi Hukum Islam dijelaskan bahwa: "Yang berhak mengajukan permohonan isbat nikah ialah suami atau istri, anak-anak mereka, wali nikah, dan pihak yang berkepentingan".

Adanya Ketentuan yang membolehkan isbat nikah seperti diatur dalam pasal 7 Kompilasi Hukum Islam tersebut memberikan isyarat bahwa secara substansial peraturan yang berlaku di Indonesia mengakui keabsahan sebuah pernikahan yang belum tercatat, dan berdasarkan alasan-alasan yang dicantumkan dalam rincian ayat (3) Kompilasi Hukum Islam tersebut pernikahan dapat dicatatkan dan diisbatkan, kedaan ini menjadikan pernikahan mendapat pengakuan secara administratif. Pasal 7 Kompilasi Hukum Islam di atas juga telah memberi peluang bagi perkawinan-perkawinan yang tidak dicatat untuk kemudian mencatatkan diri sebagimana mestinya, kondisi ini juga dinilai dapat menguntungkan pelaku perkawinan tidak dicatat, bersamaan dengan ini juga merupakan tanggung jawab bagi lembaga yang berwenang untuk merealisasikan peluang bagi orang yang ingin mewujudkan kondisi perkawinannya diakui secara hukum sehingga mempunyai kekuatan hukum yang pasti.

Tatacara isbat nikah merupakan eksistensi dan indepedensi Pengadilan Agama sejak lahirnya Undang-undang Nomor 3 Tahun 2006 tentang perubahan atas Undangundang Nomor 7 Tahun 1989 tentang Peradilan Agama dimana Peradilan Agama memiliki kedudukan yang sama dengan peradilan lain dan satu atap dibawah Mahkamah Agung, dengan sebab tersebut maka Peradilan Agama dituntut mampu melaksanakan undang-undang tersebut dengan sebaikbaiknya sebagi lembaga yang melayani publik dalam mencari keadilan.

Isbat nikah merupakan perkara yang tidak mengandung sengketa atau voluntair, dan Pengadilan Agama memiliki kompetensi untuk menangani masalah tersebut dengan syarat bila dikehendaki undang-undang. Pada prinsipnya pengadilan tidak mencari-cari perkara melainkan perkara tersebut telah menjadi kewenangannya, dan pasal 7 Kompilasi Hukum Islam tersebut telah memberikan kompetensi absolut yang luas bagi Pengadilan Agama terhadap perkara isbat tersebut. Isbat nikah merupakan permohonan agar akad nikah yang dilaksanakan dimasa lalu dilegalkan dan diakui secara hukum akibat tidak memiliki bukti autentik perkawinannya, adapun prosedur yang harus dipenuhi oleh pemohon adalah sebagai berikut:

1. Suami atau istri, janda atau duda, anakanak, wali nikah dan pihak yang berkepentingan dalam proses perkawinan itu sebagai pemohon, mengajukan permohonan tertulis kepengadilan;

2. Permohonan diajukan ke Pengadilan Agama di tempat tinggal pemohon; dan

3. Permohonan harus memuat:

a) Identitas pihak (pemohon/para pemohon);

b) Posita atau alasan-alasan/dalil yang mendasari diajukannya permohonan; dan

c) Petitum atau hal yang dimohon petusannya dari pengadilan.

Ketentuan isbat nikah tersebut terdapat dalam PERMENAG Nomor 3 Tahun 1975, dalam pasal 39 ayat (4). Ketentuan tersebut hanya berlaku bagi perkawinan yang dilangsungkan sebelum adanya Undang-Undang Nomor 1 Tahun 1974, bukan perkawinan sesudah lahirnya undang-undang tersebut. Ketentuan tersebut memberikan peluang kepada Pengadilan Agama untuk mempergunakan kompetensinya dalam masalah ini dengan alasan yang lain selain alasan isbat pada perkawinan yang terjadi sebelum lahirnya undang-undang Nomor 1 Tahun 1974 tadi sesuai dengan ijtihad hakim dalam memberi rasa keadilan bagi para pemohon.

Seringkali pengajuan isbat nikah tersebut diiringi dengan pengajuan sahnya anakanak yang dilahirkan dari perkawinan yang tidak dicatat dengan tujuan mendapatkan pengesahan yang sama seperti isbat nikah, hal tersebut disebabkan munculnya fenomena yang terdapat dalam masyarakat jika anak yang lahir tidak dapat diakui oleh catat- 
an sipil sebagai anak yang lahir dari perkawinan yang sah, maka perlu adanya pertimbangan yang matang dikarenakan banyak fenomena didaerah-daerah tertentu di Indonesia tidak mau menerima jika anaknya dinyatakan lahir dari seorang ibu dan hanya ada hubungan keperdataan dengan ibu tanpa menyebutkan nama bapak dari anak tersebut. $^{42}$

Pengajuan anak yang disertakan dalam isbat nikah tersebut harus dibuktikan secara autentik oleh yang bersangkutan sebab bias saja terjadi bahwa seorang laki-laki mengingkari anak yang dikandung oleh seorang istri sebagaimana dijelaskan dalam pasal 44 Undang-Undang Perkawinan Nomor 1 Tahun 1974 dan pasal 102 Kompilasi Hukum Islam, dan pada ayat (2) undang-undang tersebut memberikan wewenang pada pengadilan untuk memberikan keputusan sah tidaknya anak atas permintaan pihak yang berkepentingan.

Tentunya pihak pengadilan memerlukan proses dalam memutuskan sah tidaknya anak dengan prosedur dan aturan yang berlaku sesuai hukum yang ada, pada pasal 55 Undang-undang Perkawinan Nomor 1 Tahun 1974 menjelaskan bahwa:

1. Asal usul anak hanya dapat dibuktikan dengan akta kelahiran yang autentik, yang dikeluarkan pleh pejabat yang berwenang;

2. Bila akta kelahiran tersebut dalam ayat (1) pasal ini tidak ada, maka pengadilan dapat mengeluarkan penetapan tentang asal usul seorang anak setelah diadakan pemeriksaan yang teliti berdasarkan bukti yang memenuhi syarat; dan

3. Atas ketentuan pengadilan tersebut ayat (2) pasal ini maka instansi pencatat kelahiran yang ada dalam daerah hukum pengadilan yang bersangkutan mengeluarkan akta kelahiran bagi anak yang bersangkutan.

42 Andi Syamsu Alam, Beberapa Permasalahan Hukum di Lingkungan UNDILAG, Disampaikan dalam Rapat Kerja Nasional Mahkamah Agung RI Jajaran Pengadilan Tingkat Banding dari Empat Lingkungan Peradilan seluruh Indonesia, Ketua Muda UNDILAG Mahkamah Agung, Tanggal 24 September Tahun 2009.
Salah satu bukti yang mendukung pembuktian anak tersebut sesungguhnya hanya di tangan seorang istri yang mengetahui benih siapa yang dikandungnya, akan tetapi kondisi ini akan memunculkan diskriminasi dan menyudutkan pihak perempuan dengan tidak menutup kemungkinan memberi peluang pada laki-laki untuk mengingkari, dan pembuktian yang dilakukan pihak perempuan tersebut bukan hal yang mudah dilakukan sehingga menempatkan perempuan pada keputusasaan. ${ }^{43}$

Upaya lain dalam pembuktian anak sebagai anak yang sah dari perkawinan tidak dicatat adalah dengan menuntut pertanggungjawaban suami, kondisi ini dapat menggunakan upaya hukum sesuai dengan yang diatur dalam Undang-undang Tentang Perlindungan Anak Nomor 23 Tahun 2002 pasal 13 menjelaskan bahwa: Setiap anak selama dalam pengasuhan orang tua, wali atau pihak lain manapun yang bertanggung jawab atas pengasuhan berhak mendapat perlindungan dan perlakuan dari:

1. Diskriminasi;

2. Eksploetasi baik ekonomi maupun seksual;

3. Penelantaran;

4. Kekejaman, kekerasan dan penganiayaan;

5. Ketidakadilan; dan

6. Perlakuan salah lainnya.

Dalam hal orang tua, wali, atau pengasuh anak melakukan segala bentuk perlakuan sebagaimana dimaksud di atas, maka pelaku dikenakan ancaman hukuman pidana penjara paling lama 5 tahun dan/atau denda paling banyak Rp100.000.000,00-.

\section{F. Penutup}

Perkawinan bukan semata-mata mengikat hubungan antara satu orang laki-laki dan perempuan, tapi menimbulkan konsekuensi yang sangat luas tidak hanya pada pelaku pernikahan tersebut melainkan juga anakanak akibat perkawinan, keluarga, masyarakat dan negara. Dengan demikian, pernikahan tidak dianggap selesai dengan hanya ter-

43 Ismail Hasani (ed), Referensi Bagi Hakim Pengadilan Agama Tentang Kekerasan dalam Rumah Tangga (Jakarta: Komnas Perempuan. 2008), hlm. 75. 
jadinya akad nikah, itu sejalan dengan perubahan dan perkembangan hukum Islam dalam format perundang-undangan hukum keluarga di Indonesia khususnya dan di dunia muslim pada umumnya, maka pencatatan perkawinan merupakan pembaharuan hukum Islam demi tertibnya administrasi keluarga dan kependudukan, hal ini penting karena hukum keluarga dianggap sebagai inti syari'ah dan dipandang sebagai pintu gerbang untuk masuk lebih jauh ke dalam agama Islam.

\section{Daftar Pustaka}

'Utsmân, Muhammad Ra'fat. t.th. 'Aqd alZawwâj: Arkânuhû wa Syurûthu Shihatihî fî al-Fiqh al-Islâmî. t.t.: t.pn.

Abdurrahman. 1986. Himpunan Peraturan Perundang-undangan tentang Perkawinan. Jakarta: Akademika Pressindo.

Basyir, Ahmad Azhar. 1996. Hukum Perkawinan Islam. Yogyakarta: Fakultas Hukum UII.

Depertemen Agama, Pedoman Pencatatan Nikah (Jakarta: t.pn. 2003), hlm. 73-77.

Effendi, Satria. 2004. Problematika Hukum Keluarga Kontemporer. Jakarta: Balitbang Depag RI.

Hadikusuma, Hilman. 2006. Hukum Perkawinan Indonesia Menurut: Perundangan, Hukum Adat, Hukum Agama. Bandung: Mandar Maju.

Hamka, Sejarah Umat Islam (Jakarta: Bulan Bintang. 1976), Jilid II, hlm. 53.

Hasani, Ismail (ed). 2008. Referensi Bagi Hakim Pengadilan Agama Tentang Kekerasan dalam Rumah Tangga. Jakarta: Komnas Perempuan.

http://www.mail-archive.com/belajar-Islam @yahoogroup.com/msg00228.html, diakses tanggal 29 September 2014.

Jafizham, T. 2005. Persintuhan Hukum di Indonesia dengan Hukum Perkawinan Islam. Jakarta: PT. Mestika.

Lev, Daniel S. 1972. Islamic Courts in Indonesia: a Study of The Political Bases of
Legal Institutions. Los Angeles: University of California Press.

Mudzhar, Mohammad Atho. 1993. FatwaFatwa Majelis Ulama Indonesia: Sebuah Studi tentang Pemikiran Hukum Islam di Indonesia 1975-1988. Jakarta: Dwibahasa.

Mugniyyah, Muhammad Jawâd al-. t.th. alFigh 'alâ madzâhib al-Khamsah. Beirut: Dâr al-Kitâb al-'Ilmiyyah.

Nasution, Khoerudin. 2007. Hukum Perdata Keluarga Islam Indonesia dan Perbandingan Hukum Perkawinan di Dunia Muslim. Yogyakarta: Academia dan Tazzaf.

Noer, Deliar. 1983. Administrasi Islam di Indonesia. Jakarta: Rajawali Pers.

Prawirohamidjojo, R. Soetedjo. 1988. Pluralisme dalam Perundang-Undangan Perkawinan di Indonesia. Surabaya: Universitas Airlangga Press.

Saptaningrum, Indriaswari Dyah. 2000. Sejarah UU Nomor 1 Tahun 1974 tentang Perkawinan dan Pembakuan Peran Gender, dalam Perspektif Perempuan. Jakarta: Lembaga Bantuan Hukum Asosiasi Perempuan untuk Keadilan.

Satrio, J. 1991. Hukum Harta Perkawinan. Bandung: Citra Adytia Bakti.

Shâbûnî, Muhammad 'Alî al-. 1999. Tafsîr Âyât al-Ahkâm. Beirut: Dâr al-Kutûb al'Alamiyyah.

Shâbûnî, Muhammad 'Alî al-. t.th. Rawâ'i' alBayân: Tafsîr âyât al-Ahkâm. Beirut: Dâr al-Fikr.

Sosroatmodjo, Arso dan A. Wait Aulawi. 1975. Hukum Perkawinan di Indonesia. Jakarta: Bulan Bintang.

Sultan Hamengku Buwono X. 2007. Catatan Seorang Raja Tentang Peradilan Agama, dalam Varia Peradilan: Majalah Hukum. Tahun ke-XII, No. 262 September Tahun 2007.

Suwondo, Nani. 1992. Kedudukan Wanita Indonesia dalam Hukum dan Masyarakat. Jakarta: Ghalia Indonesia.

Syaybanî, al-. t.th. Ikhtilâf al-'Ammah al'Ulamâ'. Jakarta: Dâr al-Kutûb al'Ilmiyyah.

Zahrah, Muhammad Abû. 1950. al-Ahwâl alSyakhshiyyah. Beirut: Dâr al-Fikr. 